\title{
Faktor Risiko Obesitas dan Profil Lipid Darah pada Mahasiswa Baru Universitas Riau
}

\author{
Elda Nazriati ${ }^{1}$, Arfianti $^{2}$, Ismawati $^{3}$
}

\begin{abstract}
Obesity is a substansial public-health crisis in numerous developing country including Indonesia. Morbidity and mortality in adult population is increased in individuals who were overweight in adolescence even if they lose the extra weight during adulthood. Many factor influencing occurence of obesity, such as food pattern and activity pattern. The aims of this study was to describe risk factor of obesity of obese students. Samples were 2006's obese students of Riau University who had doing medical Check-up in Balai Kesehatan of Riau University. A descriptive study conducted on 27 obese students in Riau University class 2006. variables of this study are risk factor of individual and family, food pattern, and activity pattern. Obese criterian was taken by measured BMI. Food pattern and activity pattern was taken by using questionnaire. This study showed that 15 students $(55,5 \%)$ wereobese II (BMI > 30), $100 \%$ students are central obesity, $59 \%$ students had mild consumtion risk factor and 22\% students had high consumtion risk factor. 16 $\%$ student had mild and $74 \%$ student had high activity risk factor.
\end{abstract}

Keywords: obesity, food pattern, activity pattern, lipid profile

Prevalensi obesitas mengalami peningkatan di seluruh dunia dan sudah menjadi epidemi. Di Amerika Serikat prevalensi kelebihan berat badan meningkat dari $5 \%$ pada tahun 1960 , menjadi 15,5 $\%$ pada tahun $1999-2000 .{ }^{1}$ Kegemukan pada anak usia 6-14 tahun di jepang meningkat dari 5\% tahun 1974 menjadi $10 \%$ pada tahun $1993 .^{2} \quad$ Penelitian Departemen Kesehatan (Depkes) pada tahun 19961997 pada 26 kota di Indonesia, prevalensi overweight adalah $17,5 \%$, dan obesitas $4,7 \% .^{3}$ Berdasarkan perkiraan 210 juta penduduk Indonesia tahun 2000, jumlah penduduk yang overweight diperkirakan mencapai 76,7 juta $(17,5 \%)$ dan pasien obesitas berjumlah lebih dari 9,8 juta $(4,7 \%)$ sehingga disimpulkan bahwa overweight dan obesitas di Indonesia telah menjadi masalah besar. ${ }^{4}$

\footnotetext{
1. Penulis untuk korespondensi: Bagian Fisiologi Kedokteran Fakultas Kedokteran Universitas Riau, Alamat: Jl.Diponegoro No.1, Pekanbaru. Telp: 0761- 839264 ext 209.

2. Bagian Biologi Fakultas Kedokteran Universitas Riau

2. Bagian Biokimia Fakultas Kedokteran Universitas Riau
}

Banyak penelitian telah mengungkapkan bahwa terjadinya peningkatan prevalensi penyakit kardiovaskuler, hipertensi, diabetes mellitus, dan penyakit kronik lainnya sering berhubungan dengan peningkatan indeks massa tubuh .5 Penumpukan lemak di jaringan adiposa berhubungan dengan morbiditas dan mortalitas. ${ }^{6}$ Timbulnya berbagai penyakit ini dikenal sebagai komorbiditas. Komorbiditas obesitas dan overweight mulai terlihat bila terdapat abnormalitas kolesterol total $(\geq 200$ $\mathrm{mg} / \mathrm{dl})$, HDL kolesterol ( $\leq 40 \mathrm{mg} / \mathrm{dl})$, LDL kolesterol $(\geq 160 \mathrm{mg} / \mathrm{dl})$, trigliserid $(\geq 150 \mathrm{mg} / \mathrm{dl})$, tekanan darah diastolik $\geq 90 \mathrm{mmHg}$ dan sistolik $\geq 140$ mmHg. Banyak negara mempunyai perbedaan dalam batas obesitas yang membawa dampak kesehatan. Menurut penelitian Soegih (2004), untuk orang Indonesia risiko komorbiditas mulai meningkat pada IMT 24,38 kg/m2 dan lingkar pinggang (LP) $86,25 \mathrm{~cm}^{3}$

Obesitas dapat terjadi apabila pemasukan energi lebih besar dibandingkan penggunaannya, diet yang kaya akan sumber energi seperti lemak dan 
karbohidrat akan menyebabkan kegemukan apabila tidak diiringi dengan aktifitas fisik yang cukup. ${ }^{1}$ Obesitas pada usia muda dilaporkan berhubungan dengan peningkatan risiko morbiditas pada masa dewasa meskipun tidak terlihat dampak kesehatan yang merugikan. ${ }^{7}$ Penelitian menunjukkan adanya hubungan antara kelebihan berat badan pada masa remaja dengan dampak kesehatan yang merugikan 55 tahun berikutnya. ${ }^{1}$

Obesitas merupakan hasil akhir dari interaksi banyak faktor. Beberapa faktor yang dihubungkan dengan obesitas antara lain perilaku diet, aktifitas fisik, psikologis, usia, kelebihan berat badan pada masa anak-anak, faktor genetik, dan faktor lingkungan. Dari penelitian diduga bahwa 25\% faktor yang mempengaruhi obesitas merupakan faktor genetik ${ }^{1}$. Meskipun faktor genetik memegang peranan penting dalam menentukan asupan makanan dan metabolisme, faktor gaya hidup dan faktor lingkungan merupakan penyebab utama obesitas pada kebanyakan orang. ${ }^{8}$ Dua faktor yang berhubungan dengan gaya hidup modern yang memicu terjadinya obesitas adalah pola konsumsi berlebih dan pola aktivitas yang cenderung kurang aktif. ${ }^{9}$ Hasil penelitian di Amerika menunjukkan adanya hubungan pola konsumsi makanan dengan obesitas ${ }^{10}$, begitu pula dengan pola aktivitas fisik. ${ }^{11}$

Mulai bergesernya pola makan orang Indonesia dimana asupan lemak hewani penduduk Indonesia meningkat $157 \%$ dibandingkan 15 tahun yang lalu, menyebabkan risiko kematian akibat penyakit kardiovaskuler di Indonesia juga meningkat. ${ }^{12}$ Sebagian besar remaja (12-20 tahun) memiliki pola konsumsi makanan yang tidak seimbang. ${ }^{13}$ Pemilihan makanan juga tidak didasarkan pada kandungan gizi tetapi sekadar bersosialisasi, untuk kesenangan, dan supaya tidak kehilangan status. ${ }^{14}$ Jumlah penduduk usia muda yang melakukan latihan fisik juga terus menurun dari tahun ke tahun. Hampir $50 \%$ penduduk usia muda tidak melakukan latihan fisik yang rutin. ${ }^{13}$ Berdasarkan hal ini penulis tertarik mengetahui profil pola konsumsi, pola aktifitas fisik, dan lipid darah pada mahasiswa obese dan non obese.

\section{METODE}

Penelitian ini merupakan penelitian observasional untuk mendapatkan gambaran faktor risiko obesitas berupa pola konsumsi dan pola aktifitas fisik, dan gambaran profil lipid darah pada mahasiswa obese dan non obese. Subyek penelitian ini adalah seluruh mahasiswa Universitas Riau Angkatan 2006 yang mengalami obesitas dan memeriksa kesehatan di Balai Kesehatan Unri pada bulan Agustus 2006, sebagai kontrol adalah mahasiswa baru non obese dengan jumlah yang sama. Kriteria inklusi subyek penelitian adalah bersedia mengisi kuesioner dan tidak sedang menjalani program penurunan berat badan. Pada penelitian ini didapatkan 27 orang mahasiswa obese dan diambil 27 orang mahasiswa non obese sebagai kontrol. Variabel penelitian adalah pola konsumsi, pola aktifitas fisik, dan profil lipid darah.

Untuk mendapatkan data pola konsumsi dan pola aktifitas fisik, subyek penelitian diberikan kuesioner yang sudah diujicobakan. IMT ditentukan dengan mengukur rasio antara berat badan $(\mathrm{Kg})$ dan kuadrat tinggi badan $(\mathrm{m})$. Berat badan diukur dengan hanya memakai pakaian yang sudah diketahui beratnya, sedangkan tinggi badan diukur dalam satuan sentimeter dalam keadaan tanpa menggunakan alas kaki. Subyek digolongkan obesitas bila IMT $\geq 25$, sesuai dengan standar obesitas Asia Pasifik. ${ }^{15}$ Profil lipid darah terdiri dari kadar kolesterol, trigliserida, LDL, dan HDL. Pengukuran lipid darah dilakukan dengan mengambil darah vena setelah 12 jam puasa yang dianalisis menggunakan metode analisis laboratorium rutin dengan enzymatic colorimetric.

\section{HASIL}

Subyek penelitian ini terdiri dari 27 orang mahasiswa baru yang obese dan 27 mahasiswa baru non obese. Kelompok obese terdiri dari 13 laki-laki dan 14 perempuan, sedangkan pada kelompok nonobese terdiri dari 12 laki-laki dan 15 perempuan. Karakteristik subyek penelitian dicantumkan pada Tabel 1 dan Tabel 2. 
Tabel 1. Karakteristik subyek penelitian

\begin{tabular}{llll}
\hline No & Karakteristik & Obese & Nonobese \\
1 & Rerata IMT & 32,55 & 20,21 \\
2 & Rerata Lingkar perut & $97,37 \mathrm{~cm}$ & $72,16 \mathrm{~cm}$ \\
3 & Ibu atau keluarga ibu menderita kencing & $14,8 \%$ & $7,4 \%$ \\
& Manis & $59,2 \%$ & $44,4 \%$ \\
4 & Kegemukan pada waktu kecil & $59,2 \%$ & $53,3 \%$ \\
5 & Kegemukan pada anggota keluarga & $25,9 \%$ & $29,6 \%$ \\
6 & Orang tua berpendidikan tinggi & $62,9 \%$ & $40,7 \%$ \\
7 & Berasal dari keluarga ekonomi menengah & & \\
& ke atas &
\end{tabular}

Gambaran skor pola konsumsi pada mahasiswa berdasarkan 13 pertanyaan yang diajukan disajikan pada Tabel 2.

Tabel 2. Skor Pola Konsumsi Mahasiswa

\begin{tabular}{ccc}
\hline Skor & Frekuensi & $\%$ \\
1 & 2 & 3,6 \\
2 & 5 & 9,1 \\
3 & 4 & 7,3 \\
4 & 9 & 16,4 \\
5 & 7 & 12,7 \\
6 & 7 & 12,7 \\
7 & 6 & 10,9 \\
8 & 5 & 9,1 \\
9 & 3 & 5,5 \\
10 & 2 & 3,6 \\
11 & 2 & 3,6 \\
12 & 1 & 1,8 \\
13 & 1 & 1,8
\end{tabular}

Tabel 2 di atas dapat dilihat bahwa skor pola konsumsi adalah antara 1,0- 14,0. Frekuensi terbesar adalah pada skor 4,00 dan frekuensi terendah adalah pada skor 12,00 dan 14,0. Cut of point skor pola konsumsi pada mahasiswa obese dan non obese adalah 5,5. Subyek digolongkan pola konsumsi risiko rendah jika skor $<5,5$ dan pola konsumsi risiko tinggi jika skor $\geq 5,5$. Profil risiko obesitas berdasarkan skor pola konsumsi pada mahasiswa obese dan non obese disajikan pada Gambar 1.

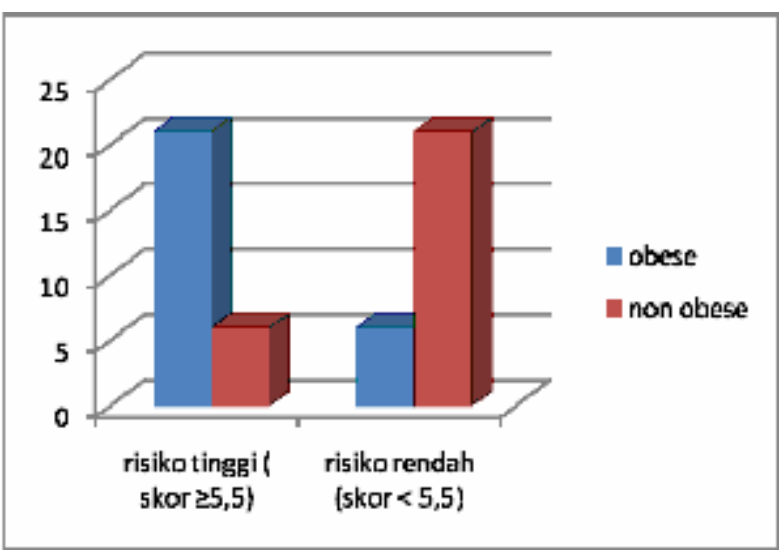

Gambar 1. Profil Risiko Obesitas pada Mahasiswa Obese dan Non Obese Berdasarkan Pola Konsumsi

Gambar 1 di atas terlihat bahwa pola konsumsi risiko tinggi terdapat pada 21 orang $(77,8 \%)$ mahasiswa obese dan 6 orang $(22,2 \%)$ mahasiswa non obese, sedangkan pola konsumsi risiko rendah terdapat pada 6 orang $(22,2 \%)$ mahasiswa obese dan 21 orang $(77,8 \%)$ mahasiswa non obese.

Gambaran skor pola aktifitas fisik pada mahasiswa berdasarkan 6 pertanyaan yang diajukan yang disajikan pada Tabel 3 . 
Tabel 3. Skor Pola Aktifitas Fisik Mahasiswa

$\begin{array}{ccc}\text { Skor } & \text { Frekuensi } & \% \\ 1 & 3 & 5,5 \\ 2 & 13 & 23,6 \\ 3 & 8 & 14,5 \\ 4 & 9 & 16,4 \\ 5 & 16 & 29,1 \\ 6 & 5 & 9,1\end{array}$

Berdasarkan Tabel 3 di atas dapat dilihat bahwa skor pola aktifitas fisik adalah antara 1,00-6,00. Frekuensi terbesar adalah pada skor 5,0 dan frekuensi terendah adalah pada skor 1,00. Cut of point pola aktifitas fisik mahasiswa obese dan non obese adalah 4,0. Subyek digolongkan menjadi pola aktifitas fisik risiko rendah jika skor $<4,0$ dan pola aktiftas risiko tinggi jika skor $\geq 4,0$. Profil faktor risiko obesitas pada mahasiswa berdasarkan skor pola aktifitas fisik disajikan yang disajikan pada Gambar 2:

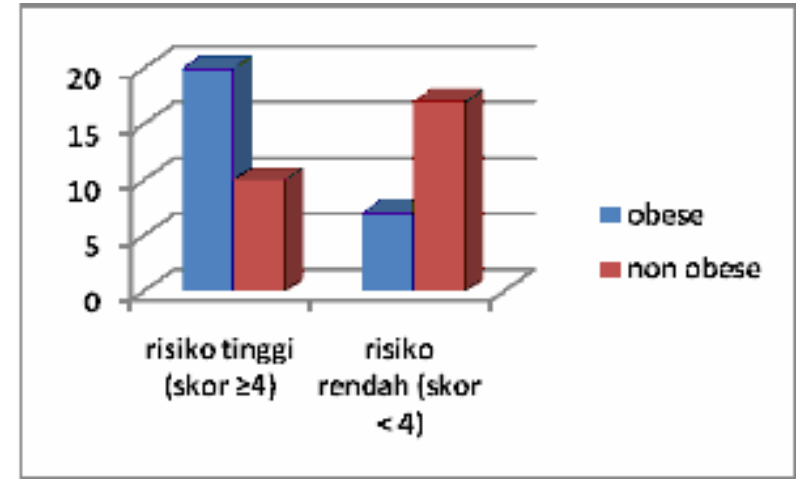

Gambar 2. Profil Skor Pola Aktifitas Fisik pada Mahasiswa Obese dan Nonobese

Berdasarkan gambar 2 di atas terlihat bahwa pola aktifitas fisik risiko tinggi terdapat pada 20 orang $(66,6 \%)$ mahasiswa obese dan 7 orang $(33,3$ $\%)$ mahasiswa non obese, sedangkan pola aktifitas fisik risiko rendah terdapat pada 7 orang $(29,2 \%)$ mahasiswa obese dan 17 orang $(70,8 \%)$ mahasiswa non obese. Abnormalitas Profil lipid darah pada mahasiswa yaitu kolesterol total ( $\geq 200 \mathrm{mg} / \mathrm{dl}$ ), HDL kolesterol $(\leq 40 \mathrm{mg} / \mathrm{dl})$, LDL kolesterol $(\geq 160$ $\mathrm{mg} / \mathrm{dl})$, dan trigliserid $(\geq 150 \mathrm{mg} / \mathrm{dl})$, disajikan pada Gambar 3.

Pada Gambar 3 tampak bahwa abnormalitas profil lipid darah lebih banyak pada pada mahasiswa obese dibandingkan non obese yaitu abnormalitas trigliserida $(\geq 150 \mathrm{mg} / \mathrm{dl})$ pada 1orang mahasiswa obese dan tidak ada seorangpun pada mahasiswa non obese, abnormalitas kholesterol ( $\geq 200 \mathrm{mg} / \mathrm{dl}$ ) terdapat pada 10 orang mahasiswa obese dan tidak seorangpun pada mahasiswa non obese. Abnormalitas HDL $(\leq 40 \mathrm{mg} / \mathrm{dl})$ terdapat pada 5 orang mahasiswa obese dan 2 orang pada mahasiswa non obese . abnormalitas LDL ( $\geq 160 \mathrm{mg} / \mathrm{dl})$ terdapat pada 3 orang mahasiswa obese dan 2 orang mahasiswa non obese.

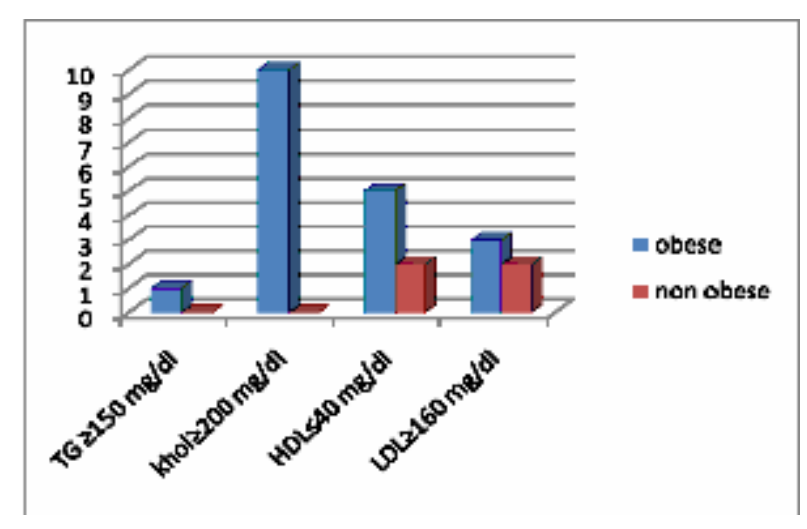

Gambar 3. Abnormalitas profil lipid darah pada mahasiswa obese dan nonobese

Untuk membandingkan rerata skor pola konsumsi, skor pola aktifitas, dan profil lipid darah pada mahasiswa obese dan non obese dilakukan uji Mann-Whitney. Hasil uji statistik disajikan pada Tabel 4:

Tabel 4. Hasil Uji statistik perbedaan rerata skor pola konsumsi, skor aktifitas fisik dan profil lipid darah mahasiswa obese dan non obese

\begin{tabular}{lrrrrrr}
\hline & Skor konsumsi & skor aktifitas & trizliserida & koles terol & HDL & LDL \\
\hline M arm-Whitney U & 99.000 & 160.500 & 158.500 & 257.000 & 302.000 & 284.500 \\
Wilcoxon W & 477.000 & 538.500 & 536.500 & 635.000 & 680.000 & 662.500 \\
Z & -4.622 & -3.618 & -3.566 & -1.860 & -1.082 & -1.384 \\
A symp. Sig.(2-tailed) & .000 & .000 & .000 & .063 & .279 & .166 \\
\hline
\end{tabular}

a. Grouping Variable: IMT 
Berdasarkan Tabel 4 diketahui bahwa terdapat perbedaan bermakna rerata skor pola konsumsi dan skor pola aktifitas fisik mahasiswa obese dan non obese $(p<0,05)$. Untuk profil lipid darah terdapat perbedaan bermakna rerata kadar trigliserida $(p<0,05)$, tetapi tidak terdapat perbedaan bermakna pada rerata kadar kolesterol, HDL, dan LDL.

\section{PEMBAHASAN}

Berdasarkan data karakteristik subyek penelitian didapatkan pada kelompok mahasiswa non obese didapatkan rerata IMT 20,21, dan rerata lingkar perut 72,16. Pada kelompok mahasiswa obese rerata IMT subyek penelitian adalah 32,55, dan rerata lingkar perut $97,37 \mathrm{~cm}$. Pada mahasiswa kelompok obese terdapat 12 orang mahasiswa yang diklasifikasikan obese tingkat I (IMT 25-29,9 kg/ $\left.\mathrm{m}^{2}\right)$, dan 15 orang $(55,5 \%)$ mahasiswa yang diklasifikasikan obesitas tingkat II (IMT > $30 \mathrm{~kg} /$ $\mathrm{m}^{2}$ ). Obesitas tingkat I memiliki risiko kesehatan tingkat sedang sampai berat, sedangkan obese tingkat II mempunyai risiko kesehatan berat sampai sangat berat. IMT berkorelasi kuat dengan lingkar pinggang, dan digunakan bersama-sama untuk meramalkan risiko komorbiditas. Pada penelitian komposisi tubuh di beberapa daerah di Indonesia didapatkan bahwa pada umur, gender, dan IMT yang sama dibandingkan dengan orang Belanda, lemak tubuh orang Indonesia 5\% lebih tinggi. ${ }^{15}$

Menurut jenis obesitas 27 orang (100\%) kelompok mahasiswa obese diklasifikasikan sebagai obesitas sentral yaitu dengan lingkar pinggang $\geq$ $90 \mathrm{~cm}$ untuk pria dan $\geq 80 \mathrm{~cm}$ untuk wanita. Obesitas sentral merupakan salah satu faktor sindroma metabolik. Lemak daerah abdomen terdiri dari lemak subkutan dan lemak intra abdominal. Jaringan lemak intraabdominal terdiri dari lemak viseral dan intraperitoneal. Lemak subkutan daerah abdomen sebagai komponen obesitas sentral mempunyai korelasi kuat dengan resistensi insulin seperti lemak viseral. Vena porta merupakan saluran pembuluh tunggal bagi jaringan adiposa dan berhubungan langsung dengan hati. Mobilisasi lemak bebas akan lebih cepat dari daerah viseral dibandingkan lemak daerah subkutan. Aktifitas lipolitik yang besar dari lemak viseral merupakan kontributor terbesar asam lemak bebas dalam sirkulasi. $^{15}$
Pada penelitian Soegih (2004) didapatkan bahwa risiko timbulnya komorbiditas mulai meningkat pada IMT $24,38 \mathrm{~kg} / \mathrm{m}^{3}$ dan lingkar pinggang $86,25 \mathrm{~cm}$ untuk kadar gula darah puasa, sedangkan untuk kadar trigliserida timbulnya komorbiditas mulai meningkat pada IMT $24,91 \mathrm{~kg} /$ $\mathrm{m}^{3}$ dan lingkar pinggang $89,25 \mathrm{~cm} .^{3}$

Berdasarkan data karakteristik subyek penelitian juga didapatkan pada mahasiswa obese faktor yang menonjol adalah kegemukan pada waktu kecil $(59,2 \%)$, kegemukan pada keluarga $(59,2 \%)$, dan berasal dari golongan ekonomi menengah ke atas $(62,9 \%)$. Kegemukan pada waktu kecil merupakan salah satu faktor risiko kegemukan saat dewasa, obesitas pada masa anak-anak dan remaja umumnya menetap sampai dewasa. Sepertiga sampai dua pertiga dari anak-anak yang menderita obesitas juga menderita obesitas pada saat dewasa. ${ }^{7}$ Orang yang gemuk di waktu kecil mempunyai risiko tiga kali lebih besar untuk menderita obesitas di saat dewasa dibandingkan orang yang tidak gemuk di waktu kecil. Sel lemak dibentuk pada tahun-tahun pertama kehidupan, anak yang gemuk mempunyai sel lemak yang tiga kali lebih banyak dibandingkan anak yang tidak gemuk. Apabila saat dewasa anak yang telah mempunyai sel lemak yang banyak ini mengkonsumsi makanan dalam jumlah besar, maka ia akan mempunyai potensi kegemukan yang tiga kali lebih tinggi dibandingkan orang dengan jumlah sel lemak sedikit meskipun mereka mengkonsumsi jumlah makanan yang sama saat dewasa. ${ }^{8}$

Banyak penelitian telah menujukkan hubungan berat badan lahir dengan obesitas pada dewasa. Penelitian tersebut juga menunjukkan bahwa pertumbuhan linear yang cepat sebelum umur 7 tahun meningkatkan risiko obesitas pada dewasa. Pada penelitian "enkid" di Spanyol, berat lahir lebih dari 3500 gram dihubungkan dengan prevalensi obesitas yang lebih tinggi 1,25 kali dibandingkan dengan berat di bawah 2500 gram. Orang yang gemuk pada saat lahir atau pada usia muda bertendensi menjadi lebih gemuk pada saat dewasa. ${ }^{7}$

Pada beberapa penelitian didapatkan bahwa risiko obesitas dan overweight menurun dengan pemberian ASI eksklusif. Penurunan risiko obesitas dan overweight ini dihubungkan dengan komposisi ASI. Terdapat perbedaan yang nyata dalam jumlah energi dan protein susu formula dibandingkan ASI, 
juga terdapat perbedaan kualitas lemak. ASI mengandung lebih dari 250 zat yang memiliki aktivitas biologis yang tidak hanya mempengaruhi metabolisme pada awal kehidupan tapi juga memegang peranan penting dalam pengaturan ekspresi sejumlah gen dalam pengaturan asupan makanan, penggunaan energi serta diferensiasi dan proliferasi sel lemak. Pemberian makanan tambahan selama 4-6 bulan pertama kehidupan berhubungan dengan insidens obesitas pada masa anak-anak dan remaja yang lebih tinggi dibandingkan anak-anak yang mendapat ASI eksklusif.?

Kegemukan pada anggota keluarga lainnya juga menjadi risiko untuk kegemukan. Peluang seorang anak mengalami obesitas adalah $10 \%$ meskipun bobot badan orang tua termasuk kategori normal. Bila salah satu orang tua obesitas peluangnya menjadi $40 \%$, dan kalau kedua orang tua obese peluang anak meningkat menjadi $80 \% .{ }^{14}$ Ada beberapa alasan mengapa kegemukan pada keluarga memberikan risiko obesitas yang lebih tinggi, pertama tingkat metabolisme dan kesensitifan pusat makan di hipotalamus kemungkinan diturunkan secara genetik. Kedua pola makan dalam keluarga akan mempengaruhi seluruh anggota keluarga, dan pola makan ini umumnya tetap dibawa meskipun mereka hidup terpisah. Disamping itu tingkat stress dan respon terhadap stress umumnya juga diturunkan. ${ }^{14}$

Faktor psikologis juga berperan dalam patogenesis obesitas. Biasanya seseorang diketahui mengalami kenaikan berat badan yang besar selama atau setelah keadaan yang menekan, seperti kematian orang tua, penyakit yang berat, atau bahkan karena depresi kejiwaan. Sehingga tampak bahwa makan seringkali merupakan alat pelepas ketegangan. Apabila makan merupakan salah satu bentuk respon terhadap stress maka hal ini dapat menjadi salah satu faktor terjadinya kegemukan. ${ }^{8}$

Sampai saat ini tidak ada bukti bahwa tingkat ekonomi berpengaruh terhadap terjadinya obesitas, di negara maju obesitas lebih sering terjadi pada tingkat ekonomi rendah, sedangkan di Negara berkembang obesitas lebih sering terjadi pada tingkat ekonomi tinggi, pendidikan orang tua yang tinggi kemungkinan berhubungan dengan tingkat ekonomi ${ }^{16}$ Pada penelitian ini didapatkan bahwa tingkat ekonomi yang tinggi merupakan salah satu faktor yang dominan pada kelompok mahasiswa obese. Anak yang berasal dari keluarga dengan tingkat ekonomi yang tinggi dapat menyalurkan keinginan makannya dengan jumlah, jenis, dan frekuensi yang diinginkannya sesuai dengan kemampuannya. Konsumsi makanan yang kaya akan kalori bila tidak diimbangi dengan aktifitas fisik yang cukup dapat menyebabkan terjadinya obesitas. Dari penelitian-penelitian didapatkan tidak terdapat korelasi yang konsisten antara pendidikan orang tua dengan kejadian obesitas.

Tidak dapat dipungkiri bahwa gaya hidup pada beberapa dekade terakhir telah membawa dampak berupa meningkatnya angka kegemukan di seluruh dunia. Perkembangan teknologi komunikasi dan transportasi yang memberikan kemudahan menyebabkan berkurangnya aktifitas fisik, begitu juga dengan kemajuan teknologi yang memudahkan manusia untuk mendapatkan makanan menyebabkan asupan makanan menjadi tinggi. ${ }^{1}$

Menjamurnya makanan cepat saji diperkirakan menjadi salah satu pola konsumsi masyarakat modern. Makanan cepat saji yang tinggi gula dan lemak dengan harga murah seringkali menjadi pilihan konsumsi masyarakat kota. Saat ini di Negara Asia terjadi perubahan yang sangat cepat pada gaya hidup yang kebarat-baratan. Pada anak-anak di kotakota Jepang saat ini ditemukan bahwa total kolesterol dan LDL kolesterol plasma yang lebih tinggi dibandingkan anak-anak di Amerika Serikat. ${ }^{2}$

Pada penelitian ini didapatkan bahwa pola konsumsi risiko tinggi terdapat pada 21 orang $(77,8$ $\%)$ dan 6 orang $(22,2 \%)$ mahasiswa non obese. sedangkan pola konsumsi risiko rendah terdapat pada 6 orang $(22,2 \%)$ mahasiswa obese dan 21 orang $(77,8 \%)$ mahasiswa non obese. Berdasarkan item pernyataan tentang pola konsumsi pernyataan, beberapa hal yang menonjol pada mahasiswa kelompok obese antara lain 96,3\% responden mengaku tidak mengalami kesulitan makan, $62,9 \%$ responden mengaku porsi makan mereka lebih banyak dibandingkan dengan teman-temannya, tetapi hanya $25,9 \%$ yang menyatakan konsumsi makanan padat lebih dari tiga kali perhari. Responden yang menyukai sayur dan buah sebanyak 40,7\%, dan $62,9 \%$ menyatakan sering makan bila merasa sudah sangat lapar dan sering makan setelah berolahraga.

Porsi makan yang banyak akan menambah 
asupan jumlah kalori, jika asupan kalori yang tinggi ini tidak diimbangi dengan pengeluaran kalori yang sesuai akan mengakibatkan penumpukan sisa kalori dalam bentuk lemak subkutan. Penelitian menunjukkan mengkonsumsi makanan, terutama makanan tinggi karbohidrat, mendekati waktu tidur berhubungan dengan obesitas. Orang yang makan malam mendekati jam tidur dapat meningkatkan jumlah glukosa yang disimpan dalam bentuk glikogen dan kemudian akan disimpan dalam bentuk lemak. ${ }^{10}$ Kebiasaan makan bila sudah lapar juga dihubungkan dengan peningkatan risiko obesitas. Pada keadaan lapar orang cenderung makan lebih banyak daripada biasanya sehingga asupan kalori cenderung lebih tinggi. ${ }^{8}$

Sarapan secara teratur dapat menurunkan risiko obesitas. Orang yang tidak pernah sarapan berisiko menderita obesitas 4,5 kali lebih tinggi daripada orang yang sarapan secara teratur. Orang yang tidak sarapan merasa lebih lapar pada siang dan malam hari daripada mereka yang sarapan. Mereka akan mengkonsumsi lebih banyak makanan pada waktu siang dan malam hari. Asupan makanan yang banyak pada malam hari akan berakibat pada meningkatnya glukosa yang disimpan sebagai glikogen. Karena aktivitas fisik pada malam hari sangat rendah, kelebihan glukosa kemudian disimpan dalam bentuk lemak. ${ }^{10}$

Konsumsi serat seperti sayur dan buah akan membantu menurunkan absorbsi lemak pada saluran cerna sehingga sebagian lemak di buang bersama feses. Konsumsi makanan berserat seperti buahbuahan dan sayuran menurunkan risiko obesitas. Serat dalam buah dan sayuran (selulosa) akan membentuk massa makanan pada saluran cerna yang menimbulkan perasaan kenyang sehingga secara tidak langsung dapat mengurangi asupan bahan makanan lain seperti bahan makanan yang mengandung karbohidrat dan lemak. ${ }^{11}$

Trend restoran fast food dan kebiasaan mengemil menyebabkan memburuknya pola makan. Makanan tersebut umumnya mengandung kalori, lemak, gula dan sodium yang tinggi, tetapi rendah serat, vitamin $\mathrm{A}$, asam askorbat, kalsium, dan asam folat. ${ }^{15}$ Kandungan lemak total dan lemak jenuh dalam makanan ini merupakan komponen nutrisi yang potensial menyebabkan kelebihan berat badan. ${ }^{17}$

Orang yang memiliki kebiasaan makan di restoran memiliki risiko yang lebih tinggi menjadi gemuk daripada mereka yang makan di rumah. Hal ini disebabkan makanan yang ada di restoran umumnya mengandung lemak jenuh dan kolesterol yang lebih tinggi daripada makanan yang disediakan di rumah ${ }^{10}$. Selain itu asupan makanan meningkat sejalan dengan jumlah makanan yang tersedia karena ketika sejumlah makanan tersedia dalam porsi yang besar orang akan terus makan sampai makanannya habis atau sampai mereka benar-benar merasa kenyang. ${ }^{18}$

Penelitian yang dilakukan di Canada didapatkan bahwa prevalensi obesitas meningkat seiring dengan peningkatan risiko pola konsumsi makanan seperti melewatkan sarapan, mengudap (mengemil), sering makan di restoran, makan makanan cepat saji. ${ }^{19}$

Selain pola konsumsi, faktor lain yang berpengaruh terhadap kejadian obesistas adalah pola aktifitas fisik. Kehidupan modern menyebabkan perubahan pada pola aktifitas fisik. Dengan kemajuan teknologi terjadi kemudahan dalam mendapatkan hal-hal yang diinginkan tanpa melakukan aktifitas fisik. Kendaraan bermotor mendominasi kehidupan, dan teknologi yang ada memudahkan pekerjaan manusia. Pekerjaan yang memerlukan banyak tenaga telah digantikan oleh alat ataupun mesin yang berteknologi tinggi sehingga manusia tidak perlu lagi mengeluarkan tenaga yang besar untuk melakukannya. Semakin banyaknya sarana hiburan yang lebih menyenangkan yang dapat dimanfaatkan untuk mengisi waktu senggang seperti televisi, komputer, video game, dan digital video discs (DVDs). ${ }^{20}$

Pada penelitian ini pola aktifitas fisik risiko tinggi terdapat pada 20 orang $(66,6 \%)$ mahasiswa obese dan 7 orang $(33,3 \%)$ mahasiswa non obese, sedangkan pola aktifitas fisik risiko rendah terdapat pada 7 orang $(29,2 \%)$ mahasiswa obese dan 17 orang $(70,8 \%)$ mahasiswa non obese. Beberapa hal yang menonjol pada mahasiswa obese adalah anakanak dan remaja lebih banyak menghabiskan waktu mereka dengan menonton televisi dan bermain video game daripada berolahraga. ${ }^{13}$ Rata-rata remaja menghabiskan waktunya selama 2,5 jam per hari di depan pesawat televisi. ${ }^{14}$ Beberapa penelitian tentang aktifitas fisik yang ditemukan pada remaja Amerika antara lain adalah 14\% anak dan remaja tidak melakukan aktifitas fisik dengan intensitas 
sedang atau tinggi, dan hampir separuh remaja usia 12-21 tahun tidak melakukan aktifitas fisik secara teratur. Remaja putri mempunyai aktifitas fisik yang lebih rendah dibandingkan remaja putra, dan remaja kulit hitam mempunyai aktifitas fisik yang lebih rendah dibandingkan remaja kulit putih. Aktifitas fisik remaja semakin rendah seiring dengan peningkatan usia. Keikutsertaan remaja pada kelas olahraga menurun dari $42 \%$ pada tahun 1991 menjadi $25 \%$ pada tahun 1995 dan hanya $19 \%$ remaja yang melakukan aktifitas fisik selama 20 menit atau lebih pada kelas pendidikan olahraga.

Penelitian yang dilakukan oleh Huriyati dkk didapatkan bahwa kelompok remaja obesitas menghabiskan lebih banyak waktunya dengan melakukan kegiatan yang bersifat menetap daripada kelompok remaja yang non-obesitas. ${ }^{21}$ Hasil penelitian Ravussin et al, risiko peningkatan berat badan empat kali lebih besar pada orang dengan pola aktivitas yang kurang aktif dibandingkan mereka yang aktif. ${ }^{1}$

Aktifitas fisik dapat memperbaiki komposisi tubuh seperti meningkatkan masa otot dan menurunkan lemak tubuh total, memperbaiki profil lipid, menurunkan tekanan darah, dan mempertahankan struktur tulang yang baik pada usia tua. Sebaliknya, risiko obesitas menurun dengan kegiatan yang bersifat aktif seperti berolahraga dan

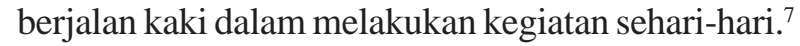
Tsukinoki et al mendapatkan risiko obesitas menurun dengan berolahraga dua kali dalam seminggu. ${ }^{22}$

Berolahraga ringan saja seperti berjalan kaki selama 2 jam perhari yang dilakukan dua kali dalam seminggu, dapat menurunkan berat badan sebesar $0,45 \mathrm{~kg}$ dalam 5 minggu. ${ }^{1}$ Peningkatan pengeluaran kalori sebesar $1250 \mathrm{~kJ}$ (300 kkal) setiap hari selama 4 bulan akan menyebabkan penurunan berat badan $4,5 \mathrm{~kg} .{ }^{23}$ Veugelers dan Fitzgerald (2005) mendapatkan risiko obesitas lebih tinggi 1,39 kali pada orang yang melakukan kegiatan sehari-hari dengan berkendaraan dibandingkan orang yang berjalan kaki. ${ }^{24}$

Olahraga juga dapat meningkatkan metabolisme basal tubuh, .selain meningkatkan pengeluaran kalori. Peningkatan metabolisme basal ini akan meningkatkan penggunaan kalori bahkan pada saat istirahat sehingga penggunaan kalori jauh lebih tinggi pada mereka yang berolahraga secara teratur daripada mereka yang tidak. ${ }^{1}$

Berdasarkan uji Mann-Whitney data profil lipid darah mahasiswa obese dan non obese didapatkan rerata kadar trigliserida mahasiswa obese lebih tinggi secara bermakna dibandingkan rerata kadar trigliserida mahasiswa non obese. Tetapi kadar kolesterol, LDL, dan HDL mahasiswa obese dan non obese tidak menunjukkan perbedaan yang bermakna. Hal ini mendukung penelitian Soegih yang menunjukkan bahwa trigliserida merupakan lipid darah yang paling sensitif dengan perubahan IMT. Peningkatan kadar trigliserida yang bermakna mulai dapat terlihat pada usia 11,9 tahun. Penelitian ini juga menyebutkan $90 \%$ dari sampel remaja obesitas 11-117 tahun telah menunjukkan peningkatan kadar trigliserida. ${ }^{25}$ Terdapat bukti kuat bahwa penurunan berat badan dapat menurunkan tekanan darah, serum trigliserida dan meningkatkan HDL. ${ }^{15}$

\section{KESIMPULAN}

Berdasarkan hasil penelitian ini dapat diambil beberapa kesimpulan yaitu:

1. Pola konsumsi risiko tinggi terdapat pada 21 orang $(77,8 \%)$ mahasiswa obese dan 6 orang $(22,2 \%)$ mahasiswa non obese, sedangkan pola konsumsi risiko rendah terdapat pada 6 orang $(22,2 \%)$ mahasiswa obese dan 21 orang $(77,8 \%)$ mahasiswa non obese.

2. Pola aktifitas fisik risiko tinggi terdapat pada 20 orang $(66,6 \%)$ mahasiswa obese dan 7 orang $(33,3 \%)$ mahasiswa non obese, sedangkan pola aktifitas fisik risiko rendah terdapat pada 7 orang $(29,2 \%)$ mahasiswa obese dan 17 orang $(70,8$ $\%)$ mahasiswa non obese.

3. Abnormalitas profil lipid darah lebih banyak terjadi pada pada mahasiswa obese dibandingkan mahasiswa non obese.

4. Uji Mann-Whitney menunjukkan terdapat perbedaan bermakna rerata skor pola konsumsi dan skor pola aktifitas fisik mahasiswa obese dan non obese $(\mathrm{p}<0,05)$. Untuk profil lipid darah terdapat perbedaan bermakna rerata kadar trigliserida $(p<0,05)$, tetapi tidak terdapat perbedaan bermakna pada rerata kadar kolesterol, HDL, dan LDL. 


\section{UCAPAN TERIMA KASIH}

Penulis mengucapkan terima kasih kepada mahasiswa baru Unri angkatan 2006 yang bersedia menjadi subyek penelitian, pihak Rektorat Unri, Fakultas Kedokteran Unri, dan Balai Kesehatan Unri yang telah memberikan kemudahan dan fasilitas bagi terlaksananya penelitian ini.

\section{DAFTAR PUSTAKA}

1. McArdle WD, Katch FI, Katch VL. Obesity and weight Control. Body Composition Assessment Exercise Physiology. $4^{\text {th }}$ Edition. Pennsylvania: Lippincott Williams \& Wilkins, 1996. 603-630

2. Deckelbaum R.J., Williams L.C.. Childhood Obesity : The Helath Issue. Obesity Research 9 S: 2001; 239-S243

3. Soegih R. BMI and WC cut offs for the risk of comorbidities of obesity in a population of Indonesia. Med J Indones 2004;13:241-5.

4. Direktorat Bina Gizi Masyarakat Departemen Kesehatan Republik Indonesia. Perkiraan Prevalensi Overweight dan Obesitas di Indonesia: Dit. BGM Depkes RI, 1997; http:// www.obesitas.web.id [diakses 22 Maret 2006]

5. Veega GL. Cardiovaskuler Outcomes for Obesity and Metabolic syndrome. Obesity Research 2002; 10:27S-30S

6. Teixera PJ., Sardinha LB., Going SB., Lohman TG. Total and Regional Fat and Serum Cardiovaskular Disease Risk Factors in Lean and Obese Children and Adolescent. Obesity Research 2001; 9 : 432- 435

7. Gil A, Koletzko B, Langin D. Increasing the Impact of European Obesity Research: Preparing for the ERA. Workshop Booklet, 2003

8. Guyton AC, Hall JE. Metabolism and Temperature Regulation. Textbook of Medical Physiology. $11^{\text {th }}$ Edition. Phyladephia: Elseiver Sauders Inc, 2006. 872 - 3

9. Stubbs RJ, Hughes DA, Johnstone AM, Horgan GW, King N, Blundell JE. A decrease in physical activity affects appetite, energy, and nutrient balance in lean men feeding ad libitum. American Journal of Clinical Nutrition 2004; 79 : 62-69
10.Ma et al. Association between Eating Patterns and Obesity in A Free-living US Adult Population. American Journal of Epidemiologi 2003; 158: 85 - 92

11. Spiegel SA, Foulk D. Reducing Overweight through a Multidisciplinary School-based Intervention. American Journal of Clinical Nutrition 2006; 14: 88-96

12. Soerjodibroto. Asia Pacific menu pattern in relation to lipid abnormalities: an Indonesian perspektive. Med J Indones 2004;13:252-7

13. Spear BA. Nutrition In Adolescence. Krause's Food, Nutrition, and Therapy. $11^{\text {th }}$ Edition. USA: Elsevier Sauders, 2004. $284-8$. 292 - 4

14.Khomsan A. Pangan dan Gizi untuk Kesehatan. Edisi 1. Jakarta: PT Raja Grafindo Persada,2003. $90-3.120-2$

15.Sugondo. Obesitas. Ilmu Penyakit Dalam. Jilid III. Edisi IV. Jakarta: Pusat Penerbitan Departemen Ilmu Penyakit dalam FKUI, 2006. $1943-4$

16.Edwards CRW, Bouchier IAD, Haslett C. Nutritional factor in Disease. Davidson's Priciples and Practice of Medicine. $17^{\text {th }}$ Edition. Edinburgh: Churchil Livingstone, 1995. 578 584

17.Pierre St-Onge M, Keller KL, Heymsfield SB. Changes in childhood food consumption patterns: a cause for concern in light of increasing body weights. American Journal of Clinical Nutrition 2003; 78: 1068-1073

18. Rolls BJ, Morris EL, Roe LS. Portion size of food affects energy intake in normal-weight and overweight men and women. American Journal of Clinical Nutrition 2002; 76: 1207-1213

19. Veugelers PJ, Fitzgerald AL. Prevalence of and risk factors for childhood overweight and obesity. Canadian Medical Association Journal 2005; 173 (6)

20.Peters, John C. Modifying the environment to reverse obesity (Essay on: Obesity and the Environment). Environmental Health Perspectives 2005 ; http://www. HighBeam Research.web [diakses 21 September 2006]

21.Huriyati E, Hadi H, Julia M. Aktivitas Fisik pada 
Remaja SLTP Kota Yogyakarta dan Kabupaten Bantul serta Hubungannya dengan Kejadian Obesitas. The Indonesian Journal of Clinical Nutrition 2004; Vol.1 No.2

22. Tsukinoki, Harimoto K, Nakayama K, Association between lifestyle factors and plasma adiponectin levels in Japanese men. Lipid in health and Disease 2005; 4:27 .

23.Olefsky JM. Obesitas. Harrison's Prisip-prinsip Ilmu Penyakit Dalam.Jakarta : EGC, 1999. 497 $-504$
24. Veugelers PJ, Fitzgerald AL. Prevalence of and risk factors for childhood overweight and obesity. Canadian Medical Association Journal 2005; 173 (6)

25.Freedman DS, Diets WH, Srinirvisan SR, Berenson GS. The relation of Overweight to cardiovascular Risk Factors among children and adolescent: The Bogalusa Heart Study. Pediatric 1999; volume 103;1175-82 